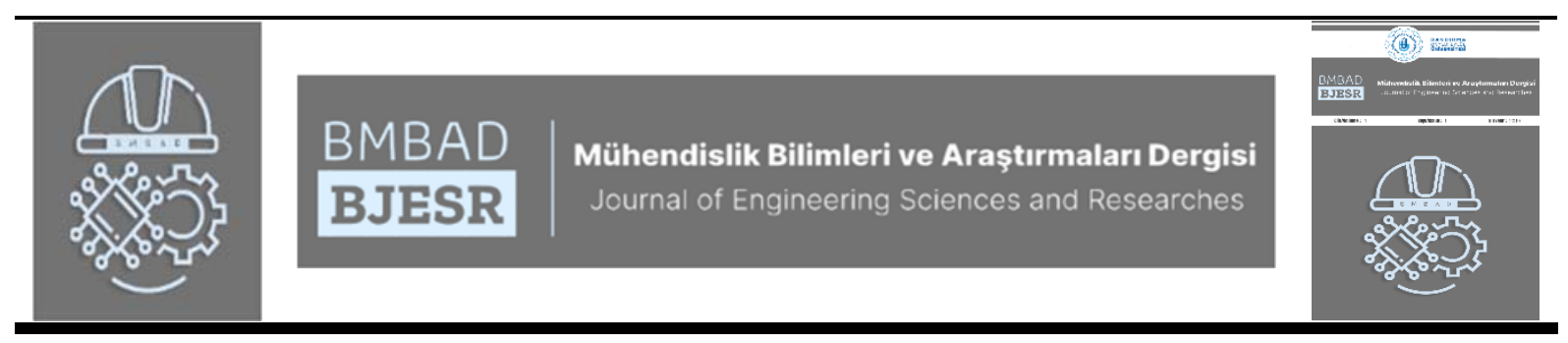

\title{
Ambulance Service For Hospital Selection: Optimization With Discrete-Event Simulation Application For Yozgat Province Of Turkey
}

\author{
Hastane Seçiminde Ambulans Hizmeti: Türkiye Yozgat I̊li Optimizasyon İle \\ Kesikli-Olay Simülasyon Uygulaması
}

\author{
Yasemin Ayaz Atalan \\ Yozgat Bozok Üniversitesi, Mühendislik ve Mimarlık Fakültesi, Yozgat,, Türkiye
}

yasemin.ayaz@bozok.edu.tr

Araştırma Makalesi/Research Article

\begin{tabular}{l}
\hline A R T I C L E I N F O \\
Article history \\
Received : 24 March 2021 \\
Accepted : 2 April 2021
\end{tabular}

Keywords:

City Hospital, University Hospital, Ambulance Service, Discrete-Event Simulation, Dispatching Time \begin{abstract}
A B S T R A C T
This study aims to develop a new approach in the ambulance service to refer the patient not to the nearest hospital but to a suitable hospital that responds better to his/her illness. Due to the lack of staff and equipment in a hospital, patients are often very likely to be transferred to another hospital. A case study was performed with a discrete-event simulation method for an improved ambulance service flowchart in this research. The case study was conducted in Yozgat province of Turkey, including two hospitals (city and university), one emergency call center, and six ambulance stations. Each of them has one vehicle. The data used covers the one-year from January 2018 to January 2019. The method developed for this study resulted in a $21.14 \%$ improvement in ambulance service. The most crucial point that was noteworthy among the findings was that referral of the patient to the most appropriate hospital, rather than the nearest hospital, was important in terms of both dispatching time and the life-threatening condition of the patient.
\end{abstract}

(C) 2020 Bandirma Onyedi Eylul University, Faculty of Engineering and Natural Science. Published by Dergi Park. All rights reserved.

M A K A L E B İ L G İ S İ

Makale Tarihleri

Gönderim : 24 Mart 2021

Kabul : 2 Nisan 2021

\section{Anahtar Kelimeler:}

Şehir Hastanesi, Üniversite Araştırma Hastanesi, Ambulans Servisi, Kesikliolay Simülasyonu, Sevk Süresi

\section{Ö Z E T}

Bu çalışma, ambulans hizmetinde hastayı en yakın hastaneye değil, hastanın hastalığına daha iyi yanıt veren uygun bir hastaneye sevk etmek için yeni bir yaklaşım geliştirmeyi amaçlamaktadır. Bir hastanede personel ve ekipman eksikliği nedeniyle, hastaların başka bir hastaneye nakledilme olasılığı çok yüksektir. Bu araştırmada geliştirilmiş bir ambulans hizmeti akış şeması için ayrık olay simülasyon yöntemiyle bir vaka çalışması gerçekleştirildi. Vaka çalışması, iki hastane (şehir ve üniversite), bir acil çağrı merkezi ve altı ambulans istasyonu sahip Yozgat ilinde gerçekleştirilmiştir. Her bir ambulans istasyonun bir adet olmak üzere ambulans aracı bulunmaktadır. Kullanılan veriler Ocak 2018'den Ocak 2019'a kadar olan bir y1lı kapsamaktadır. Bu çalışma için geliştirilen yöntem ambulans hizmetinde \%21,14'lük bir iyileşme sağlanmıştır. Bulgular arasında dikkat çeken en önemli nokta, hastanın en yakın hastaneden ziyade en uygun hastaneye sevk edilmesinin hem sevk süresi hem de hastanın hayatı tehdit edici durumu açısından önemli olduğu bu çalışma ile tespit edilmiştir.

2020 Bandırma Onyedi Eylül Üniversitesi, Mühendislik ve Dağa Bilimleri Fakültesi. Dergi Park tarafından yayınlanmaktadır. Tüm Hakları Saklıdır. 


\section{INTRODUCTION}

The world-renowned ambulance service system is perceived as a healthcare unit that provides patients with medical assistance and the fastest access to the hospital. The ambulances must reach the patient locations (or emergency areas) and the hospitals in a short time [1]. Therefore, it is an action planned to be deployed where ambulance locations are likely to experience an emergency [2]. Sometimes ambulance providers are trying to run more ambulances than they can because they cannot provide services at a certain time. However, in such a case, health services will require more resources for ambulance service in terms of cost [3]. This study aimed to create a different ambulance service system by considering the available resources without any resource change.

This paper has introduced an effective solution to prevent the transfer of patients from one hospital to another hospital by changing the current ambulance service flow diagram [4]. The fact that the hospital has both insufficient human resources and equipment causes negative consequences for the patients. One of the most important of the negative sides is that the patients cannot be accepted in hospitals that cannot respond to the disease. Therefore, the patient is referred to another hospital. In the classic ambulance service diagram, the patient is assigned to the nearest hospital by the ambulance [5]-[7]. However, ambulance authorities do not consider the equipment or competence of the hospital. Because their first task is to bring the patient to the nearest hospital to eliminate the patient's life-threatening condition, sometimes such a principle works correctly. Still, today this principle needs to be reviewed by the authorities.

Many studies have proposed solutions for ambulances' locations, resources of healthcare, the number of hospitals, and so on [7]-[14]. These suggestions usually contain statistical solutions and abstract concepts [15]. For example, it has been planned to increase hospital capacity, a clear and straightforward solution for crowded locations. The effect of the results obtained in this study using the Nash equilibrium method is estimated to be very little or fewer [3]. Especially in studies conducted on ambulance locations, more concrete results have been obtained because of digital data inclusion [6], [16], [17]. Wu and Hwang determined that two ambulances were over-worked in the plot area where the study was carried out using the Tainan EMS system and emphasized that the ambulances' response times in emergencies [18]. With the identification of ambulance locations, each ambulance serves a specific area, but if more than one ambulance is needed in another region, ambulances are also notified in other locations.

In such studies, two types of approaches have been comprehensively discussed by researchers. The optimization method, which is the first approach, is preferred to solve problems by transferring real-life issues to a mathematical environment [8], [9], [19], [20]. As ambulance modelling studies are based on uncertainty, the use of stochastic, genetic and dynamic optimization models in ambulance location studies is widely used in the literature [21]-[23]. In one study, an optimization model has been developed, which minimizes ambulances' response time using the mixed genetic algorithm approach. The most suitable place and coverage areas for ambulances were determined in this research [17]. After the ambulances meet a request, the appropriate location is located in a different position or remains at the end of the request. Generally, ambulances are moved back to their former position for the next request [24], [25]. In another study for the ambulance location problem, the ambulances' response time to the demands was reduced by approximately 59 seconds using the approximate dynamic programming optimization method [16]. However, such studies do not consider the position of patients and the suitability of hospitals in the next activity.

The ambulance service system has a dynamic structure due to real-time situations [1], [16], [26]. In such structured systems, optimization methods give limited answers. Therefore, the best way for stochastic structured problems is discrete-event simulation methods [27]. This method is widely used in the literature as a second technique to solve ambulance service problems (real ambulance dispatch data) [6], [19], [28]. Some researches apply both methods (simulation-optimization) in terms of ambulance service. As in all studies, measurements of the maximum survival target and ambulances (location) of the ambulance providers for the patients were also considered in such studies [8]. A discrete-event simulation model was developed for this study. Ambulance service is embedded in a different method for the flow diagram into this model. The new flow diagram is as follows: providing an ambulance to the patient location by responding to the call from the intended patients as soon as possible, to transmit the patients' information to the surrounding hospitals, and finally to identify the hospital appropriate to the patient and to transfer the patient to the hospital. The patient must be transferred to a hospital that does not have the closest hospital but has sufficient personnel (physicians, nurses, technicians, etc.) [29] and equipment to respond to the complaints of the patients.

This study included a case study with actual ambulance dispatch data. We developed a discrete simulation program to expose the mathematical expressions of ambulance service times and locations in the study's methodology. We examined two options: 1) The nearest hospital- regardless of the disease of a patient and without the choice of the hospital, the patient to referral to the nearest hospital and then re-tour the patient from this hospital to another hospital (re-tour), 2) the most suitable hospital- adding a different step to the ambulance service flow diagram, not referring the patient to the nearest hospital, instead referring the patient to the most appropriate hospital to respond to his or her disease. All results are derived from the discrete-event simulation model, which we consider to be accurate and precise. In the following part of this study, the methodology and real-time data of the study were included in the case study. 


\section{METHODOLOGY}

\subsection{Environmental Overview of Yozgat Province}

Yozgat is one of the oldest settlements in Central Anatolian Region of Turkey that ranks 16th in terms of land area with its 14 districts. Only 9\% of the province area is covered with forests where a terrestrial and harsh climate is dominant. The summers are warm and dry and winters are rainy in Yozgat [30]. The settlement of the province is in a pit and is mostly surrounded by mountains negatively affecting the air circulation causes an increase in air pollution. As the use of fossil fuels rises with the cooling of the air, an escalation is observed in the $\mathrm{SO}_{2}$ and $\mathrm{PM}_{10}$ concentrations in the atmosphere. Therefore, the topographic structure of the city and the preferences for fuel type reduce air quality which in turn have an adverse influence on healthcare [31].

\subsection{Data of the Study}

The city of Yozgat has a total of 2 hospitals which are named Yozgat City Hospital (called "city hospital" instead of "state hospital or public hospital"-These institutions are tendered by the Turkish government to the construction companies and are recognized as new hospitals by the build-operate-transfer formula) and University Hospital. There is only one emergency call center in this city. (The telephone code of this center is used as 112 instead of 911). This city also has six ambulance vehicle stations, and the total number of ambulances vehicles employed is 6 in the center of the town [32] (see Figure 1).

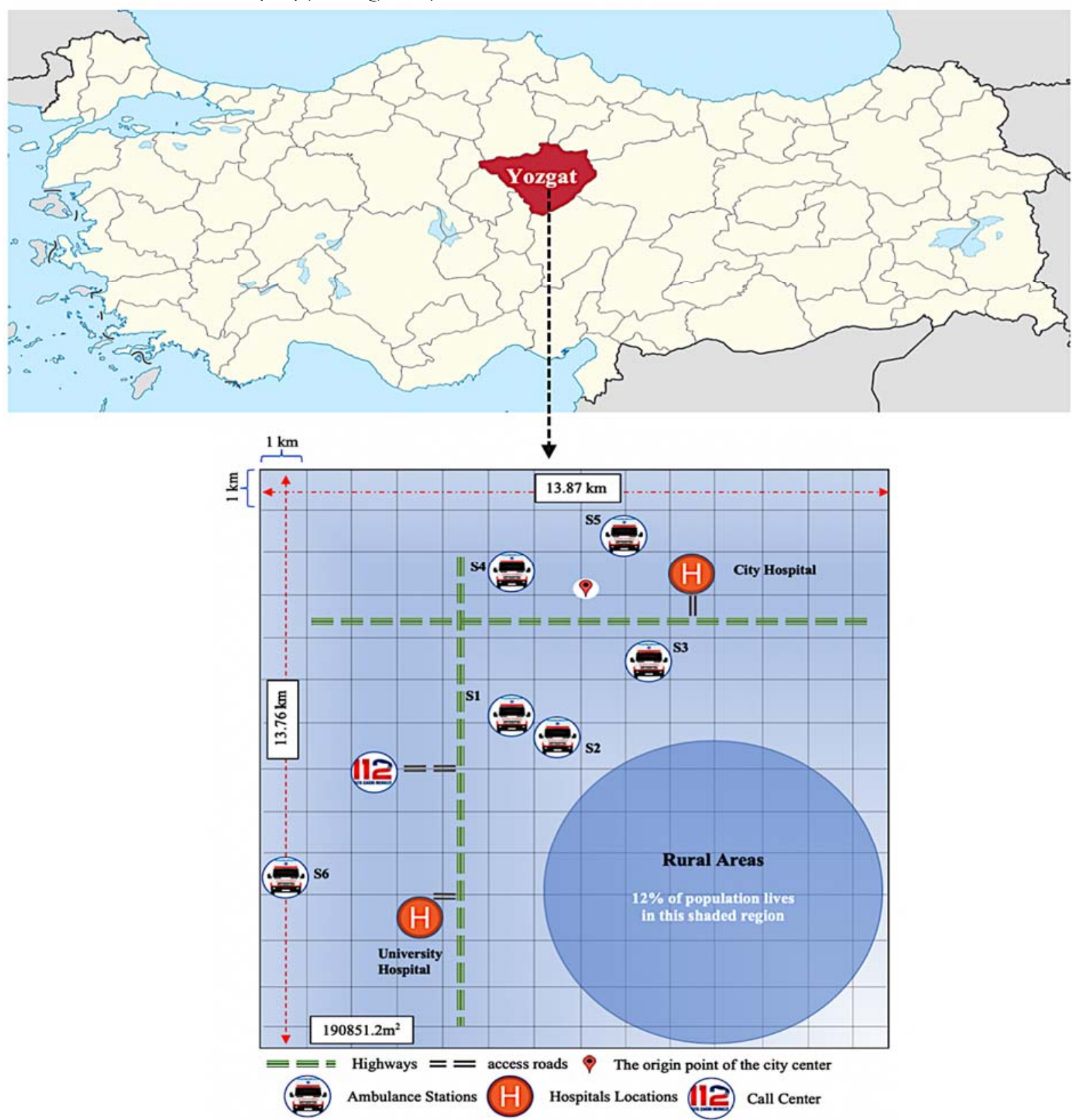

Figure 1. The map of the study area showing call center, ambulances, and hospitals locations 
The population of this city is calculated as 90163 for 2018 [33]. Approximately 15027 people are serving an ambulance, considering the number of ambulances. The ambulance system helps a distance of about $13.87 \mathrm{~km}$ for the central district of Yozgat. The data of the emergency call center used the one-year cover period from January 2018 to January 2019. The emergency call center receives approximately 23 (mean) calls per day. The numbers of calls were showed normal distribution ( $\mu_{e}=23.058, \sigma_{e}=2.335$ ). According to Figure 2, daily, at least 17 calls and up to 32 calls are received by the emergency call center.
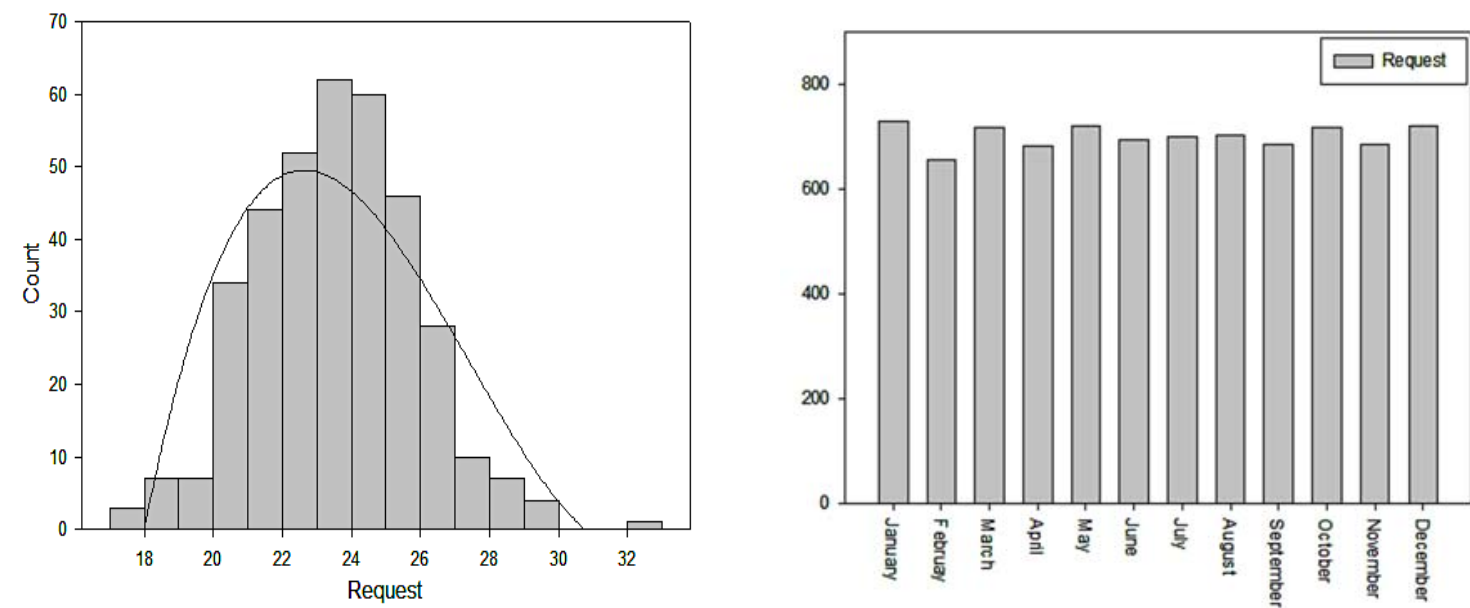

Figure 2. Histogram of requests per day and number of requests per month for the period of 2018-2019

We observed that the number of calls is mostly between 21 and 25 bands. The data-analyser tool analysed the gathered data and determined that the data had the characteristic of the logistic distribution. Higher P-value and lower Anderson-darling values designate a better fit of data ( $\mathrm{p}$-value and statistics value were calculated as 0.250 and 0.371 , respectively). The characteristic of this distribution is used as a long-tailed distribution model than the normal distribution. This distribution is already used for modeling the distributions of the data with kurtosis. Besides, this distribution is a continuous distribution defined by position parameters. The function of this distribution has only one shape and is similar to the normal distribution characteristic. The number of incoming calls is calculated as 701 (mean) monthly and 8408 (total) on an annual basis for the period of 2018-2019. Although the number of calls showed a similarity in months, it was observed that the number of calls increased in the summer months.

The fluctuations in the number of emergency calls were in the winter months, according to the data. We have connected this situation to the annual average temperature $\left(9.1^{\circ} \mathrm{C}\right)$ of Yozgat province [34]. This city's yearly average temperature is below the country's average annual temperature $\left(13.1^{\circ} \mathrm{C}\right)$ [35]. It was observed that winter is intense in this city.

According to the data obtained in the emergency call center, approximately $72 \%$ of the patients were referred to the city hospital, while $28 \%$ of the patients were referred to the university hospital. Generally, while hospital selection is made according to the severity of the injuries of the patients, the university hospital does not examine patients excluding cardiac and brain disorders outside the working hours. The first treatment of such patients with normal sickness is carried out in city hospitals. If the patient's disease severity persists, the patient is referred to the nearest provinces. Such cases occur rarely. Five steps are applied in normal ambulance services. There is no step in informing the hospital and receiving feedback from the appropriate hospital in these steps. The statistical information for the periods required for these steps is given in Table 1 .

Table 1. Statistical data for the duration of the ambulance service

\begin{tabular}{llllllllll}
\hline Definitions & Mean & $\begin{array}{l}\text { Standard } \\
\text { Deviation }\end{array}$ & Variance & Minimum & Q1 & Median & Q3 & Maximum & IQR \\
\hline Calls of Request & 1.1342 & 0.0709 & 0.0050 & 1.0008 & 1.0872 & 1.1364 & 1.1919 & 1.2475 & 0.1047 \\
Assign Ambulance & 1.5785 & 0.2793 & 0.0780 & 1.0552 & 1.3053 & 1.6631 & 1.8280 & 1.9815 & 0.5227 \\
Travel to Patient & 8.5460 & 3.0370 & 9.2260 & 2.3010 & 6.7520 & 8.6270 & 11.301 & 12.779 & 4.5490 \\
First Exam & 3.0210 & 1.2170 & 1.4810 & 1.0850 & 1.9140 & 3.1480 & 4.1110 & 4.9110 & 2.1970 \\
Travel to Hospital & 10.057 & 3.7530 & 14.087 & 3.6310 & 6.9580 & 10.071 & 13.537 & 15.793 & 6.5780 \\
\hline
\end{tabular}

Note: In statistics, data are divided into four equal parts to form quartiles. The reason for creating quartiles is to evaluate the propagation and tendency of a data set. $\mathrm{Q}_{1}(25 \%$ of the data set is less than or equal to this value), median ( $50 \%$ of the data set is less than or equal to this value), $Q_{3}(75 \%$ of the data set is less than or equal to this value), and IQR (The range between the first and third quartiles is considered (Q3-Q1)) represent the first, second and third quartile, and fourth quartile respectively. The unit of all numerical values is discussed in minutes. 
The fact that sometimes in ambulance service is not clear and precise has caused the average values of the data used in this study. Since the city determined for this study is not busy in terms of traffic, traffic density is not considered. The time required for some steps in the ambulance service flow diagram: the average time to inform the emergency call center by the patient or patient relatives is 1.15 minutes, the time taken for the emergency call center to give the address of the patient to the ambulance stations is 1.60 minutes (the average time to inform ambulance stations by the call center is between 1.05-1.98 minutes), the time used for an ambulance to reach the patient location is minimum 2.30 minutes, maximum 12.779 minutes, the first intervention of the ambulance authorities and the departure time of the patient for the hospital takes 1.08 to 4.911 minutes, respectively. The time is required a maximum of 17.93 minutes and a minimum of 3.63 minutes for a patient to reach a hospital.

Based on real-life data sets of the ambulance service system in Turkey to test, the developed method of the discreteevent simulation model was used in this study. Five steps (calls of request, assign ambulance, travel to patients, the first exam by ambulance authorities, and travel to hospitals) were applied in standard ambulance service. There was no step in informing the hospital and receiving feedback from the appropriate hospital in these steps. This extra step emphasizes having six steps in the ambulance service. The ambulance service flow diagram, which was considered for this study, was expressed as follows: One or more patients request an ambulance call (Patients dial 112. This code is used for all emergency calls in Turkey). The call center informs the stations where ambulances are located. The distance of the ambulance stations to the patient's location is determined. An ambulance suitable for the patient's location is preferred. The necessary information of health staff who make the first examination of the patient enters the system and inform all the hospitals in that area (new step). Based on the feedback received from hospitals, the patient is moved to the hospital where both the near and the appropriate healthcare providers. Figure 3 shows the network relationship between the steps discussed in this article.

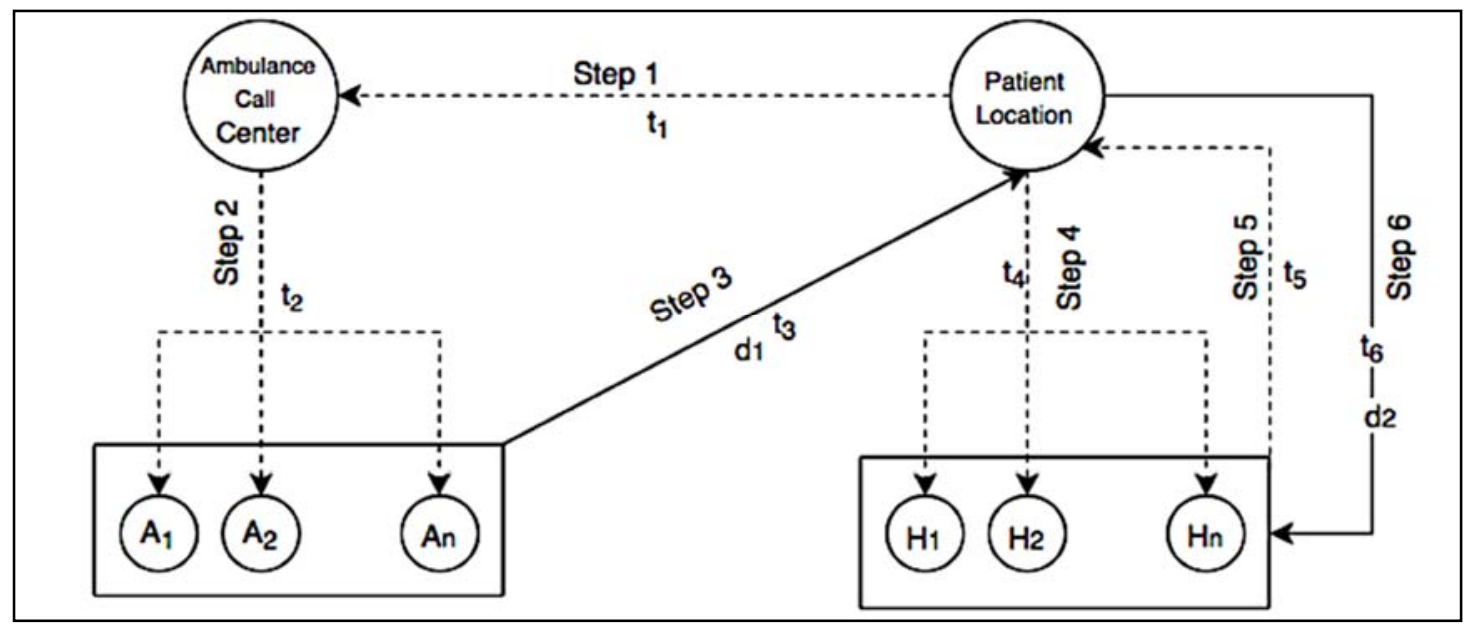

Figure 3. The network relation of the ambulance service system

Six major steps were identified for ambulance service as follows. These are;

- Step 1: The request of a new call for ambulance,

- Step 2: Identification of a suitable ambulance close to the patient,

- Step 3: Departing from the place where the ambulance is located,

- Step 4: Ambulance authorities examine the first intervention and diagnosis, and send information about the patient to the hospitals

- Step 5: Hospital(s) give feedback to the ambulance authorities by appropriate hospitals with the sufficient staff or equipment to respond to the patient's illness, and assign hospitals,

- Step 6: Ambulance departs for the appropriate hospital, and arrives at the hospital,

Some notations for expressions mathematical model are expressed as follows:

- The time of the patient talking to the emergency service center, $t_{1}$

- Time for emergency service center to inform ambulance stations, $t_{2}$

- Time for the assigned ambulance to reach patient location, $t_{3}$

- Time for the first examination and to inform the hospitals by staff, $t_{4}$

- Time for appropriate hospitals to provide feedback to ambulance authorities, $t_{5}$

- $\quad$ Time for dispatch of the patient to the appropriate hospital, $t_{6}$

- Terms expressing the vehicles of ambulances as $A_{1}, A_{2}, A_{3}, A_{4}, A_{5}$ and, $A_{6}$

- Distances of ambulances to patient locations $\left\{d_{a 1}, d_{a 2}, d_{a 3}, d_{a 4}, d_{a 5}, d_{a 6}\right\}$

- Time for the any ambulance to reach patient location, $\left\{t_{a 1}, t_{a 2}, t_{a 3}, t_{a 4}, t_{a 5}, t_{a 6}\right\}$

- Distance of the appropriate ambulance near the patient location, $d_{1}$

- Distances of the nearest hospital, which is not the closest, to patient locations, $d_{2}$

- $\quad$ Terms expressing hospitals as $H_{c}$ and $H_{u}$ 
- Distances of hospitals to patient locations, $d_{h c}, d_{h u}$

- Time for the any ambulance to reach hospital location, $\left\{t_{h c}, t_{h u}\right\}$

- The time required to transfer the patient from any hospital to a suitable hospital, $t_{r}$

- Distance traveled from any hospital to a suitable hospital, $d_{r}$

The network relation of the ambulance service system was examined from four different points. These are the definition of the steps, the locations where the service starts and ends, the times required for the steps, and the distances between the steps (see Table 2).

Table 2: Definition of time and distance for ambulance service

\begin{tabular}{llllcl}
\hline Steps & Definition & Starting Location & Ending Location & Time & Distance \\
\hline 1 & Calls of Request & Patient & Call Center & $t_{1}$ & - \\
2 & Assign Ambulance & Call Center & Station & $t_{2}$ & $d_{a 1}, d_{a 2}, \ldots d_{a 6}$ \\
3 & Travel to Patient & Station & Patient & $t_{3}$ & $d_{1}$ \\
4 & Exam, Inform Hospitals & Patient & Patient & $t_{4}$ & $d_{h 1}, d_{h 2}$ \\
5 & Feedback, Assign Hospital & Patient & Hospital & $t_{5}$ & - \\
6 & Travel to Hospital & Patient & Hospital & $t_{6}$ & $d_{2}$ \\
\hline
\end{tabular}

\subsection{Optimization Models}

The first objective was to minimize the time between the call from the patient and the delivery of the patient to the hospital in the real system. The equation was formulated as:

$$
\operatorname{Min}[\text { Service Time }]=t_{1}+t_{2}+t_{3}+t_{4}+t_{5}+t_{6}
$$

The time required to transport the patient to the hospital was expressed as, $t_{6}$. The following prerequisite was needed for the value of $t_{6}$ :

$$
t_{6}=t_{h c}+t_{h u} ;\left\{\begin{array}{c}
\text { if city hospital was aasigned, then } t_{h u}=0 \\
\text { if university hospital was aasigned, then } t_{h c}=0
\end{array}\right.
$$

Patient calls do not affect our problem at certain intervals. Therefore, patient calls were determined not as a statistical distribution but as a certain time. The second objective was to minimize the ambulance close to the location of the patient. The formulation of the second objective function was expressed as:

$$
d_{1}=\operatorname{Min}\left\{d_{a 1}, d_{a 2}, \ldots d_{a 6}\right\}
$$

The constraint to determine the ambulance close to the patient's location, where $\left(d_{a 1}, d_{a 2}, \ldots d_{a 6}\right\}$ are binary. So;

$$
\begin{aligned}
& d_{a 1}=(0,1)\left\{\begin{array}{r}
1, \text { if the ambulance } 1 \text { is located at station } \\
0, \text { if not }
\end{array}\right. \\
& d_{a 2}=(0,1)\left\{\begin{array}{r}
1, \text { if the ambulance } 2 \text { is located at station } \\
0, \text { if not }
\end{array}\right. \\
& d_{a 6}=(0,1)\left\{\begin{array}{r}
1, \text { if the ambulance } 6 \text { is located at station } \\
0, \text { if not not }
\end{array}\right.
\end{aligned}
$$

The third objective was to determine the hospital close to the patient's location, and the formulation was stated as below:

$$
d_{2}=\operatorname{Min}\left(d_{h c}, d_{h u}\right\}
$$

The constraint to determine the ambulance close to the patient's location, where $\left(d_{h c}, d_{h u}\right\}$ are binary. So;

$$
d_{h c}=(0,1) ;\left\{\begin{array}{c}
1, \quad \text { if city hospital was assigned and } \\
\text { there are sufficient staff and equipment required } \\
0, \quad \text { if the city hospital was assigned but } \\
\text { if there are not sufficient staff and equipment required }
\end{array}\right.
$$




$$
d_{h u}=(0,1) ;\left\{\begin{array}{l}
1, \quad \text { if the university hospital was assigned and } \\
\text { there are sufficient staff and equipment required } \\
0, \quad \text { if the university hospital was assigned but } \\
\text { if there are not sufficient staff and equipment required }
\end{array}\right.
$$

Suppose a new patient is referred from one hospital to another hospital (city-university hospital or university-city hospital) in the worst-case scenario. In that case, several additions to the optimization model are required as below.

- The distance between the two hospitals was $12.4 \mathrm{~km}$, and this distance lasted approximately 15.4 minutes (without traffic) in Yozgat. The time required for the ambulance service to be completed re-formulated as follows:

$$
t_{1}+t_{2}+t_{3}+t_{4}+t_{5}+t_{6}+t_{r}
$$

- The distance travelled during the ambulance service was re-expressed as below:

$$
\operatorname{Min}\left\{d_{a 1}, d_{a 2}, \ldots d_{a 6}\right\}+\operatorname{Min}\left(d_{h c}, d_{h u}\right\}+d_{r}
$$

Although an optimization model has been developed for the problems, discrete event simulation models were accepted to solve the issues with a stochastic structure (the uncertainty of the next situation). The fact that there were three different objective functions showed that this study had a stochastic structure. Therefore, the simulation technique was to use in order to overcome this problem.

\subsection{Discrete-Event Simulation Models}

The discrete-event simulation program was often used to get accurate results by deriving scenarios (which is a long time and costly to implement without the discrete event simulation technique). A computer discrete event simulation software with $\mathrm{C}^{++}$programming language, three dimensional, and oriented objects was used in this study. In the discrete-event simulation program, each unit was taken as $1 \mathrm{~km}^{2}$. Staff walking and vehicle speeds were defined in real-time throughout the run and updated each time dynamically. The speed of the ambulance vehicles and walking of the staff were considered as $50 \mathrm{~km} / \mathrm{h}$, and $60 \mathrm{~m} / \mathrm{min}$ in the developed model for this study, respectively. The scheduling system was not used for the resources used in the model. The same amount of resource utilization was ensured, considering the 24-hour operating principle for the ambulance service system. The icons and resources used in the model perform the same activities as the real-life routine. Each process specified in the model was perceived as a series of resource activities in the ambulance service system.

\section{CASE STUDY}

There are two conditions for the referral of the patient to the hospital after the initial treatment. First of all, ambulance authorities provide information about the patient to hospitals instantly. The hospital, which will respond to the patient's disease, has a priority. The distance from the hospital to the patient constitutes the criteria for this study as the second case. If there are many hospitals in a city, it is a priority to choose the closest hospital to the patient from the hospitals to respond to the patient's disease. However, there are two hospitals in this city, which means that there are two options for transferring the patient. Patient locations were determined in six different districts in the central region of Yozgat. Six different situations have been considered, including the distance of these regions to each ambulance location. Six different conditions have been considered, including the distance of these regions to each ambulance location.

A discrete event simulation model has been developed for situations that belong to scenarios. The data was embedded by considering the patients' distance to ambulances and hospitals in the simulation model - the screen display of the simulation model, as shown in Figure 4. The simulation model was run separately for 36 conditions. 


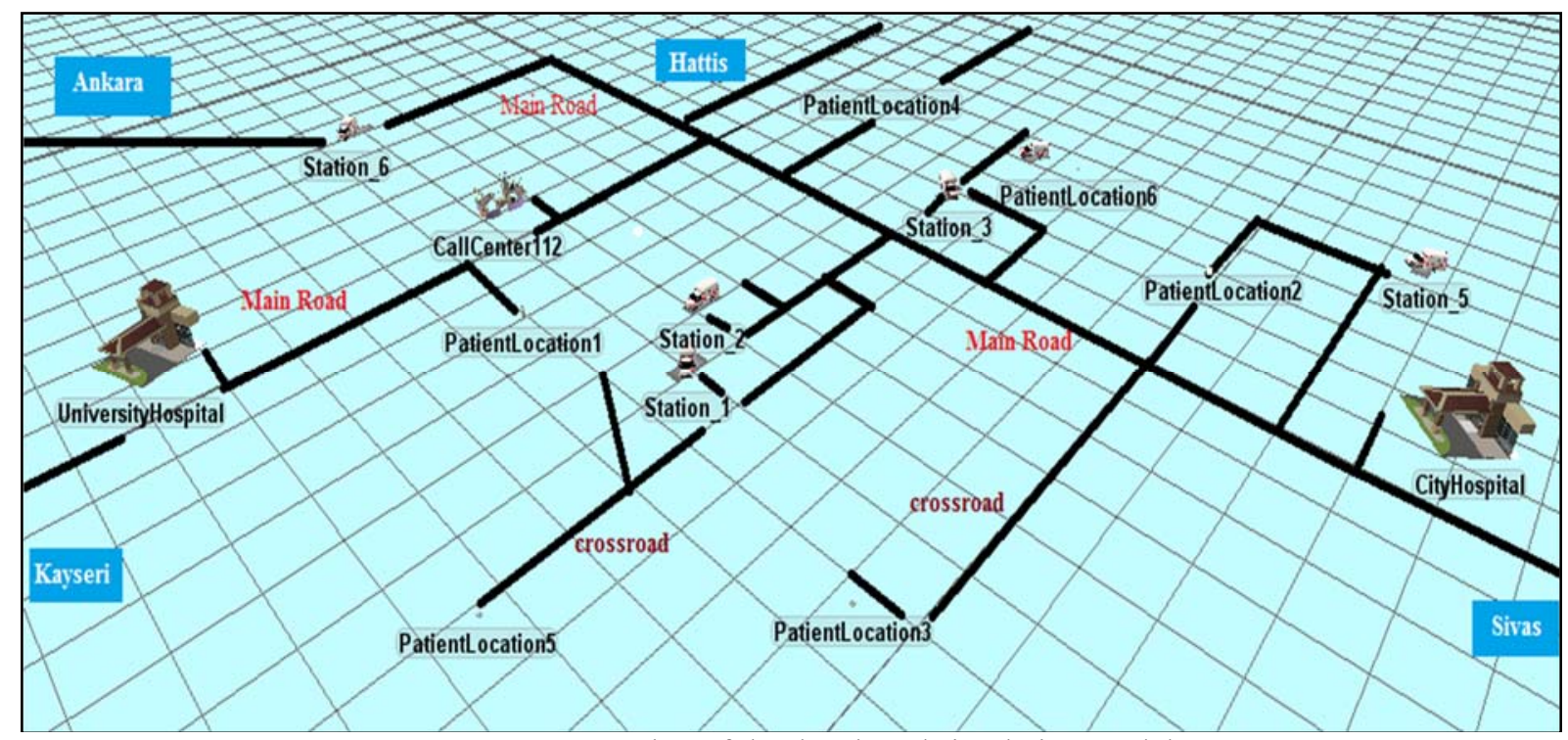

Figure 4. Screenshot of the developed simulation model

Thirty-six different scenarios were developed for the case study to establish ambulance service steps (the number of scenarios can be increased or decreased) (see Table 3). Different situations were considered for these scenarios. The origin of the scenarios was the distance of the patient locations to both the hospital and the ambulance stations. The conditions of the scenario were determined as the suitability (not close) of the hospital to respond to the patient's disease and the appropriateness of the ambulance near the patient location.

Table 3: Situations for scenarios derived for simulation

\begin{tabular}{|c|c|c|c|c|c|c|c|c|c|c|c|c|c|c|c|c|c|c|}
\hline \multirow{2}{*}{$\begin{array}{l}\text { Patient } \\
\text { Locations }\end{array}$} & \multicolumn{2}{|c|}{$A_{1}$} & \multicolumn{2}{|c|}{$A_{2}$} & \multicolumn{2}{|c|}{$A_{3}$} & \multicolumn{2}{|c|}{$A_{4}$} & \multicolumn{2}{|c|}{$A_{5}$} & \multicolumn{2}{|c|}{$A_{6}$} & \multicolumn{2}{|c|}{$\boldsymbol{H}_{c}$} & \multicolumn{2}{|c|}{$H_{u}$} & \multicolumn{2}{|c|}{ Re-tour } \\
\hline & $d_{a 1}$ & $t_{a 1}$ & $d_{a 2}$ & $t_{a 2}$ & $\underline{a 3}$ & $t_{a 3}$ & $d_{a 4}$ & $t_{a 4}$ & $d_{a 5}$ & $t_{a 5}$ & $d_{a 6}$ & $t_{a 6}$ & $d_{h c}$ & $t_{h u}$ & $d_{h u}$ & $t_{h u}$ & $d_{r}$ & $t_{r}$ \\
\hline $\mathrm{L}$ & 2.3 & 5 & 3.2 & 7 & 3.8 & 7 & 3.5 & 7 & 4.8 & 8 & 6.3 & 6 & 7.4 & 12 & 5.7 & 9 & 22.8 & 31 \\
\hline Locat & 3.4 & 8 & 3.4 & 8 & 2.4 & 6 & 1.9 & 3 & 0.1 & 1 & 10.4 & 13 & 2.6 & 5 & 10.4 & 16 & 18.8 & 26 \\
\hline Lc & 2.1 & 5 & 2.0 & 5 & 0.2 & 1 & 1.2 & 5 & 2. & 6 & 5 & 12 & 4.6 & 9 & 9.4 & 14 & 20.7 & 30 \\
\hline Loc & 2.3 & 8 & 2.5 & 9 & 3.4 & 10 & 2.2 & 5 & 3.7 & 12 & 8.2 & 13 & 6.4 & 12 & 8.2 & 15 & 22.2 & 34 \\
\hline Lo & 0.5 & 2 & 0.6 & 3 & 2.1 & 6 & 2. & 0 & 3.6 & 7 & 8.1 & 12 & 4.5 & 9 & 8.2 & 13 & 20.8 & 31 \\
\hline Location 6 & 2.0 & 6 & 2.1 & 6 & 1.5 & 6 & 0.22 & 1 & 19 & 5 & 9.0 & 11 & 4.4 & 9 & 9.0 & 13 & 20.4 & 30 \\
\hline $\mathrm{Ma}$ & 3. & 8 & 3.4 & 9 & 3.8 & 10 & 3.5 & 1 & 4.8 & 12 & 10.4 & 13 & 7.4 & 12 & 10.4 & 16 & 22.8 & 34 \\
\hline Min & 0.5 & 2 & 0.6 & 3 & 0.2 & 2 & 0.22 & 1 & 0.052 & 2 & 6.3 & 6 & 2.6 & 5 & 5.7 & 9 & 18.8 & 26 \\
\hline Mean & 2.1 & 6 & 2.3 & 6 & 2.2 & 6 & 1.89 & 5 & 2.759 & 7 & 8.58 & 11 & 5 & 9 & 8.48 & 13 & 21 & 30 \\
\hline
\end{tabular}

Note: distance unit was defined as km; the time unit was defined as minutes.

\section{RESULTS AND DISCUSSIONS}

The data analysis for the case study the data obtained in the standard case (statistical analysis and ambulance service flow diagram, including five steps) were discussed in

In the first case (following the city hospital results), the referral of a patient to a hospital takes 21.99 minutes. The duration of referral of a patient to the university hospital (not the nearest hospital, but to the nearest hospital, which is available for adequate resources), lasts an average of 25.99 minutes. According to the normal ambulance service principle, the time to reach the city hospital was found to be shorter than that of a patient reach to the university hospital. The results obtained from 6 scenarios (S1, S7, S13, S19, S25, and S31) from 36 scenarios showed that the duration of reaching the university hospital was low; if the remaining scenarios are followed, the patient arrives at the city hospital at a short time.

With the new approach developed for this study, in the light of the data shown in

, we have proved that the appropriate hospital selection, the hospital is close but not suitable for the patient for the patient's disease, the choice of the hospital in the distance is correct. In

, it is understood that only scenario 2 and scenario 20 data are close to each other in terms of re-tour, but that a patient still needs a lot of time to be dispatched to the appropriate hospital. According to these scenarios, the most 
critical reason for re-tour time is close to the developed model because the patient's position is very close to the hospital. In this figure, 3 different approaches are compared. According to all ambulance locations of a patient, the time required to reach the city hospital in 6 different steps is 25.86 minutes.

In contrast, the time required for the university hospital is 29.861 minutes. However, the time needed for a patient to be transferred to a nearby hospital and then to another hospital is 35.33 minutes. It was found that a $21.14 \%$ improvement was achieved with the method developed for this study.

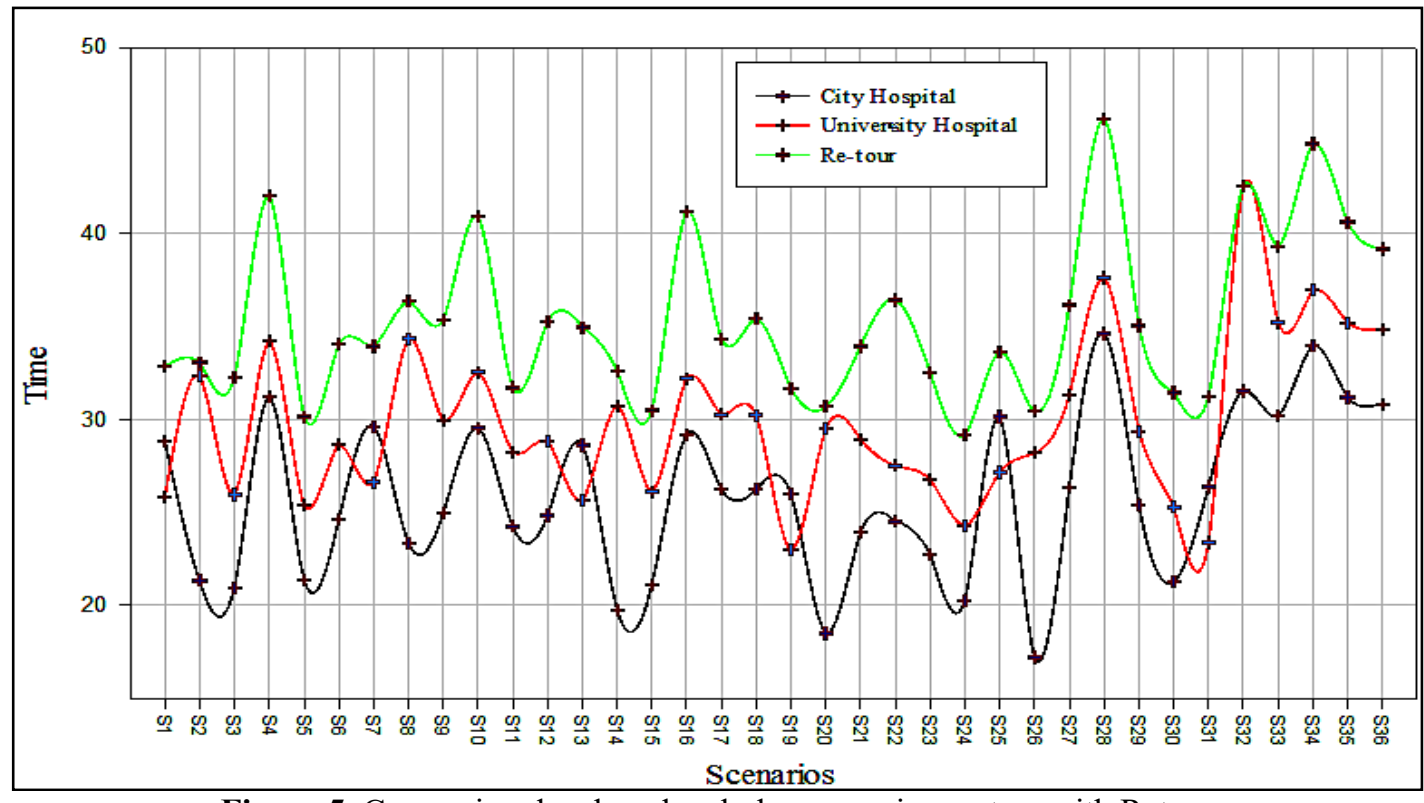

Figure 5. Comparing developed ambulance service system with Retour

This study also made an analysis considering the possibility of the worst scenario. In this scenario, when the ambulance arrives for the patient to the nearest hospital, and there are not enough resources and equipment, there is a calculation of the time that has arisen by going to another hospital. Another condition used in the worst case was that the ambulance stations are selected to be the farthest to the patient location. Since there are six different patient locations for the worst-case scenario, six different situations were questioned. Data for comparison of this situation were discussed in Figure 6.

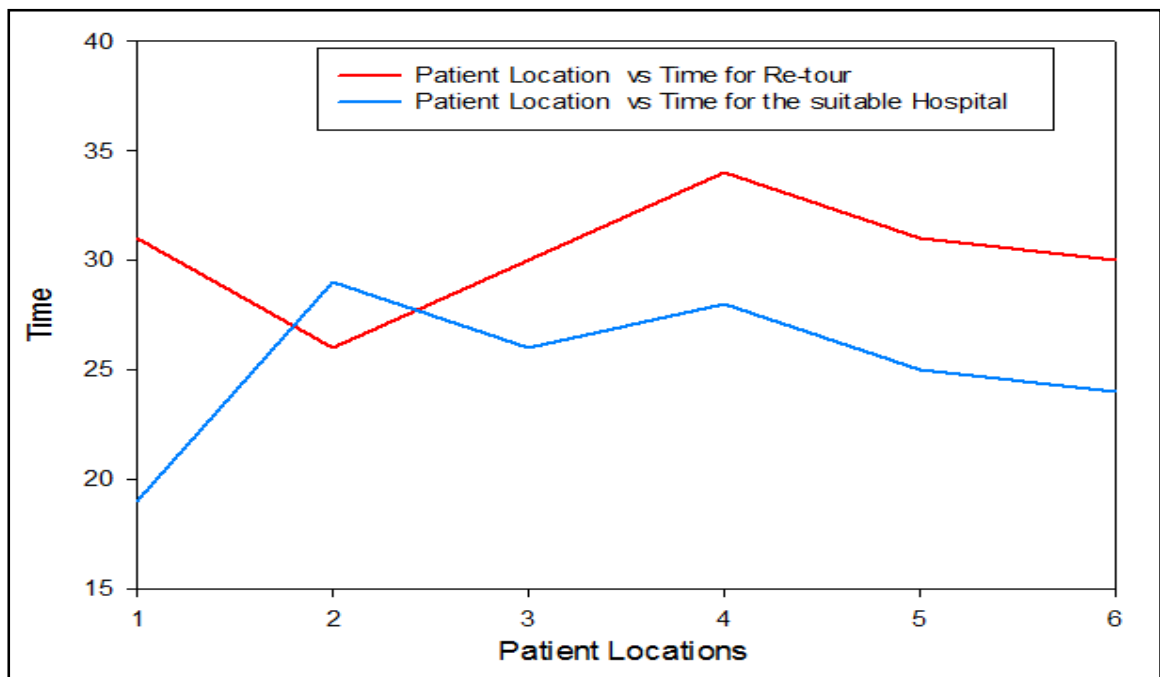

Figure 6. The comparison of the time between Re-tour and the Suitable Hospital

According to Figure 6, only the second patient's location gave the lowest hospitalization time in the case of six different patient locations. We have observed that the transport of the patient from one hospital to another hospital is at risk both in terms of time and the patient's life. The time required is 30.33 minutes for a patient to re-tour and the ambulances to reach the last hospital after contacting the patient location. The time required is 25.16 minutes for the patients to be dispatched to a proper hospital. Wei Lam et al. reduced the ambulance service time from 12.69 minutes to 7.08 minutes using a discrete simulation technique [36]. Ong et al. decreased the ambulance response time from 10.1 minutes to 7.1 minutes using the geospatial time analysis method [37]. As a result, considering the worst-case scenario (the most distance between the locations of ambulances and hospitals), we 
observed that it is appropriate to move the patient to the most appropriate hospital, which is not the closest. In short, this study aimed to reduce the ambulance response time by proposing a new step to the ambulance service. It has been observed that the ambulance service has been out of the traditional, and a $21.14 \%$ improvement has been achieved with the new method.

\section{CONCLUSIONS}

A case study was performed with a discrete-event simulation method in this research. Data was collected for the ambulance service of the City of Yozgat, located in the center of Turkey's borders. The case study includes two hospitals, one center of the emergency call, and six emergency stations to find the ambulance vehicles. The data used covers a one-year period of 2018-2019. Thirty-six scenarios were considered, with the worst scenario for this study. In the results obtained for 36 scenarios, according to all ambulance regions of the patient, the average time required to reach the city hospital in 6 different steps was 25.86 minutes, and the average time required for the university hospital was calculated as 29.861 minutes. However, the average time required to transport a patient to a nearby hospital and then to another hospital is 35.33 minutes. Considering the worst scenario (the most distance between the ambulance and hospital locations), we found it appropriate to dispatch the patient to the most appropriate hospital. The time required was calculated as 25.167 minutes for patients to be dispatch to a suitable hospital. Thus, a $21.14 \%$ improvement was achieved with the help of the developed method in this study. The most critical point that is noteworthy among the findings was that referral of the patient to the most appropriate hospital, rather than the nearest hospital, is important both in terms of time and the life-threatening of the patient. This study was first conducted in a small city with a population of 100000 . It was observed that the results obtained were positive. This study shows that it is more important to apply it in larger cities. However, the accuracy of the data to be collected in these cities and the correct development of the applied method is essential.

\section{Conflict of interest}

The author declares that there is no conflict of interest.

\section{KAYNAKÇA}

[1] T. Van Barneveld, C. Jagtenberg, S. Bhulai, and R. Van der Mei, "Real-time ambulance relocation: Assessing real-time redeployment strategies for ambulance relocation," Socioecon. Plann. Sci., vol. 62, pp. 129-142, Jun. 2018.

[2] M. Peyravi, S. Khodakarim, P. Örtenwall, and A. Khorram-Manesh, "Does temporary location of ambulances ('fluid deployment') affect response times and patient outcome?," Int. J. Emerg. Med., vol. 8, no. 1, p. 37, Oct. 2015.

[3] X. Fu, A. Presbitero, S. V. Kovalchuk, and V. V. Krzhizhanovskaya, "Coupling Game Theory and Discrete-Event Simulation for Model-Based Ambulance Dispatching," in Procedia Computer Science, Jan. 2018, vol. 136, pp. 398-407.

[4] A. Atalan, "Türkiye Sağlık Ekonomisi için İstatistiksel Çok Amaçlı Optimizasyon Modelinin Uygulanmas1," İşletme Ekon. ve Yönetim Araştırmaları Derg., vol. 1, no. 1, pp. 34-51, 2018.

[5] C.-H. Lin, C.-Y. Kao, and C.-Y. Huang, "Managing emergency department overcrowding via ambulance diversion: A discrete event simulation model," J. Formos. Med. Assoc., vol. 114, no. 1, pp. 64-71, Jan. 2015.

[6] R. McCormack and G. Coates, "A simulation model to enable the optimization of ambulance fleet allocation and base station location for increased patient survival," Eur. J. Oper. Res., vol. 247, no. 1, pp. 294-309, Nov. 2015.

[7] S. Nickel, M. Reuter-Oppermann, and F. Saldanha-da-Gama, "Ambulance location under stochastic demand: A sampling approach," Oper.

Res. Heal. Care, vol. 8, pp. 24-32, Mar. 2016.

[8] V. Bélanger, A. Ruiz, and P. Soriano, "Recent optimization models and trends in location, relocation, and dispatching of emergency medical vehicles," Eur. J. Oper. Res., vol. 272, no. 1, pp. 1-23, Jan. 2019.

[9] J. C. Dibene, Y. Maldonado, C. Vera, M. de Oliveira, L. Trujillo, and O. Schütze, "Optimizing the location of ambulances in Tijuana, Mexico," Comput. Biol. Med., vol. 80, pp. 107-115, Jan. 2017.

[10] L. Abdullah, C. W. R. Adawiyah, and C. W. Kamal, "A decision making method based on interval type-2 fuzzy sets: An approach for ambulance location preference," Appl. Comput. Informatics, vol. 14, no. 1, pp. 65-72, Jan. 2018.

[11] M. A. Zaffar, H. K. Rajagopalan, C. Saydam, M. Mayorga, and E. Sharer, "Coverage, survivability or response time: A comparative study of performance statistics used in ambulance location models via simulation-optimization," Oper. Res. Heal. Care, vol. 11, pp. 1-12, Dec. 2016.

12] G. C. Alexander, L. P. Casalino, and D. O. Meltzer, "Patient-Physician Communication About Out-of-Pocket Costs," JAMA, vol. 290, no. 7, pp. 953-958, 2003.

[13] D. C. Ferreira, R. C. Marques, and A. M. Nunes, "Pay for performance in health care: a new best practice tariff-based tool using a log-linear piecewise frontier function and a dual--primal approach for unique solutions," Oper. Res., pp. 146, Jun. 2019.

B. Topal and H. Şahin, "Sağlık sektöründe 
müşteri memnuniyetinin ölçümü: Simav Devlet Hastanesi örneği," Int. J. Econ. Policy Emerg. Econ., vol. 2, no. 1, pp. 15-30, 2017.

[15] C. Örgev, B. Topal, and H. Şahin, "İşgörenlerin Demografik Özelliklerinin Örgütsel İklim Algısına Etkisinin İstatistik Analizi: Süreyya Paşa Göğüs Hastalıkları Hastanesi Örneği,” Eur. J. Sci. Technol., vol. 19, pp. 165-175, Aug. 2020.

[16] V. Schmid, "Solving the dynamic ambulance relocation and dispatching problem using approximate dynamic programming," Eur. J. Oper. Res., vol. 219, no. 3, pp. 611-621, Jun. 2012.

[17] A. P. Iannoni, R. Morabito, and C. Saydam, "An optimization approach for ambulance location and the districting of the response segments on highways," Eur. J. Oper. Res., vol. 195, no. 2, pp. 528-542, Jun. 2009.

[18] C.-H. Wu and K. P. Hwang, "Using a Discreteevent Simulation to Balance Ambulance Availability and Demand in Static Deployment Systems," Acad. Emerg. Med., vol. 16, no. 12, pp. 1359-1366, Dec. 2009.

[19] H. Morohosi and T. Furuta, "Optimization model and simulation for improving ambulance service system,",2013.

[20] A. Atalan and C. C. Donmez, "DEVELOPING OPTIMIZATION MODELS TO EVLUATE HEALTHCARE SYSTEMS," Sigma J. Eng. Nat. Sci., vol. 38, no. 2, pp. 853-873, 2020.

[21] D. Bertsimas and Y. Ng, "Robust and Stochastic Formulations for Ambulance Deployment and Dispatch," Eur. J. Oper. Res., May 2019.

[22] S. S. W. Lam, C. B. L. Ng, F. N. H. L. Nguyen, Y. Y. Ng, and M. E. H. Ong, "Simulation-based decision support framework for dynamic ambulance redeployment in Singapore," Int. J. Med. Inform., vol. 106, pp. 37-47, Oct. 2017.

[23] M. Swalehe and S. G. Aktas, "Dynamic Ambulance Deployment to Reduce Ambulance Response Times Using Geographic Information Systems: A Case Study of Odunpazari District of Eskisehir Province, Turkey," Procedia Environ. Sci., vol. 36, pp. 199-206, Jan. 2016.

[24] A. D. Hanchate, M. K. Paasche-Orlow, K. S. Dyer, W. E. Baker, C. Feng, and J. Feldman, "Geographic Variation in Use of Ambulance Transport to the Emergency Department," Ann. Emerg. Med., vol. 70, no. 4, pp. 533-543.e7, Oct. 2017.

[25] S. Enayati, M. E. Mayorga, H. K. Rajagopalan, and C. Saydam, "Real-time ambulance redeployment approach to improve service coverage with fair and restricted workload for EMS providers," Omega, vol. 79, pp. 67-80, Sep. 2018.
[26] A. Atalan and C. Donmez, "Employment of Emergency Advanced Nurses of Turkey: A Discrete-Event Simulation Application," Processes, vol. 7, no. 1, p. 48, Jan. 2019.

27] A. Shahabi, S. Raissi, K. Khalili-Damghani, and M. Rafei, "Designing a resilient skip-stop schedule in rapid rail transit using a simulationbased optimization methodology," Oper. Res., pp. 1-31, Oct. 2019.

[28] C. Swoveland, D. Uyeno, I. Vertinsky, and R. Vickson, "A simulation-based methodology for optimization of ambulance service policies," Socioecon. Plann. Sci., vol. 7, no. 6, pp. 697-703, Dec. 1973.

[29] A. Atalan and C. C. Dönmez, "Optimizing experimental simulation design for the emergency departments," Brazilian J. Oper. Prod. Manag., vol. 17, no. 4, pp. 1-13, 2020.[30] TürkiyeCumhuriyetiÇevreveŞehircilikBakanlığ 1, "Yozgat İli," Türkiye Cumhuriyeti Çevre ve Şehircilik Bakanlığl, 2021. https://yozgat.csb.gov.tr/genel-bilgiler-i-2301.

[31] Yozgat Valiliği Çevre Ve Şehircilik İl Müdürlüğü, "Yozgat İli 2017 Yili Çevre Durum Raporu, 2017.

[32] 112 Acil Çağrı Merkezi, "Yozgat 112 Acil Çağri Merkezi Müdürlüğü,” 2020.

[33] Turkish Statitical Institute, “Adrese Dayalı Nüfus Kayit Sistemi," 2020. https://biruni.tuik.gov.tr/medas/?kn=95\&locale= tr.

[34] State Turkish Meteorological Service, "Extreme Maximum, Minimum and Average Temperatures Measured in Long Period $\left({ }^{\circ} \mathrm{C}\right), " \quad 2019$. https://www.mgm.gov.tr/veridegerlendirme/ilve-ilceler-istatistik.aspx?m=YOZGAT.

[35] Turkish State Meteorological Service, "The average temperature between 1970 and 2016 in Turkey," 2019. .

[36] S. S. Wei Lam, Z. C. Zhang, H. C. Oh, Y. Y. Ng, W. Wah, and M. E. Hock Ong, "Reducing Ambulance Response Times Using Discrete Event Simulation," Prehospital Emerg. Care, vol. 18, no. 2, pp. 207-216, Apr. 2014.

[37] M. E. H. Ong et al., "Reducing Ambulance Response Times Using Geospatial-Time Analysis of Ambulance Deployment," Acad. Emerg. Med., vol. 17, no. 9, pp. 951-957, Sep. 2010. 